\title{
CAMBRIDGE
}

\section{Healing the Republic}

The Language of Health and the Culture of Nationalism in Nineteenth-Century America

\section{Joan Burbick}

This book interprets narratives of health written by physicians, social reformers, lay healers, and literary artists in order to expose the fears and conflicts underlying the creation of national culture in America.

f35.00 net HB $0521454344 \quad 365$ pp.

Cambridge Studies in American Literature and Culture 82

\section{Walt Whitman's Native Representations}

\section{Ed Folsom}

Walt Whitman looked to many different areas of American culure to develop a distinctively American poetry. This book investigates four of the areas he found most fertile for his own poetic development: the evolution of American dictionaries, the growth of the national sport of baseball, the decimarion of American Indians, and the development of American photography.

E35.00 net HB $0521453577 \quad 215$ pp.

Cambridge Studies in American Literature and Culture 80

\section{The Love of The Last Tycoon}

\section{A Western \\ F. Scott Fitzgerald}

\section{Edited by Matthew J. Bruccoli}

This critical edition of The Love of The Last Tycoon utilises Fitzgerald's manuscript drafts, revised typescipts, and working notes to establish the first authoritative text of the work.
f30.00 net HB $052140231 \times \quad 400 \mathrm{pp}$.

The Cambridge Edition of the Works of F. Scott Fitzgerald

\section{Voices of Persuasion}

\section{Politics of Representation in 1930s America}

\section{Michael E. Staub}

This innovative study demonstrates the seldom-discussed multicultural diversity of Depression-era literature and recasts 1930s cultural history by analysing those genres characteristic of the period.
f30.00 net
HB 0521453909
$186 \mathrm{pp}$

Cambridge Studies in American Literature and Culture 78

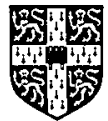

\section{CAMBRIDGE}




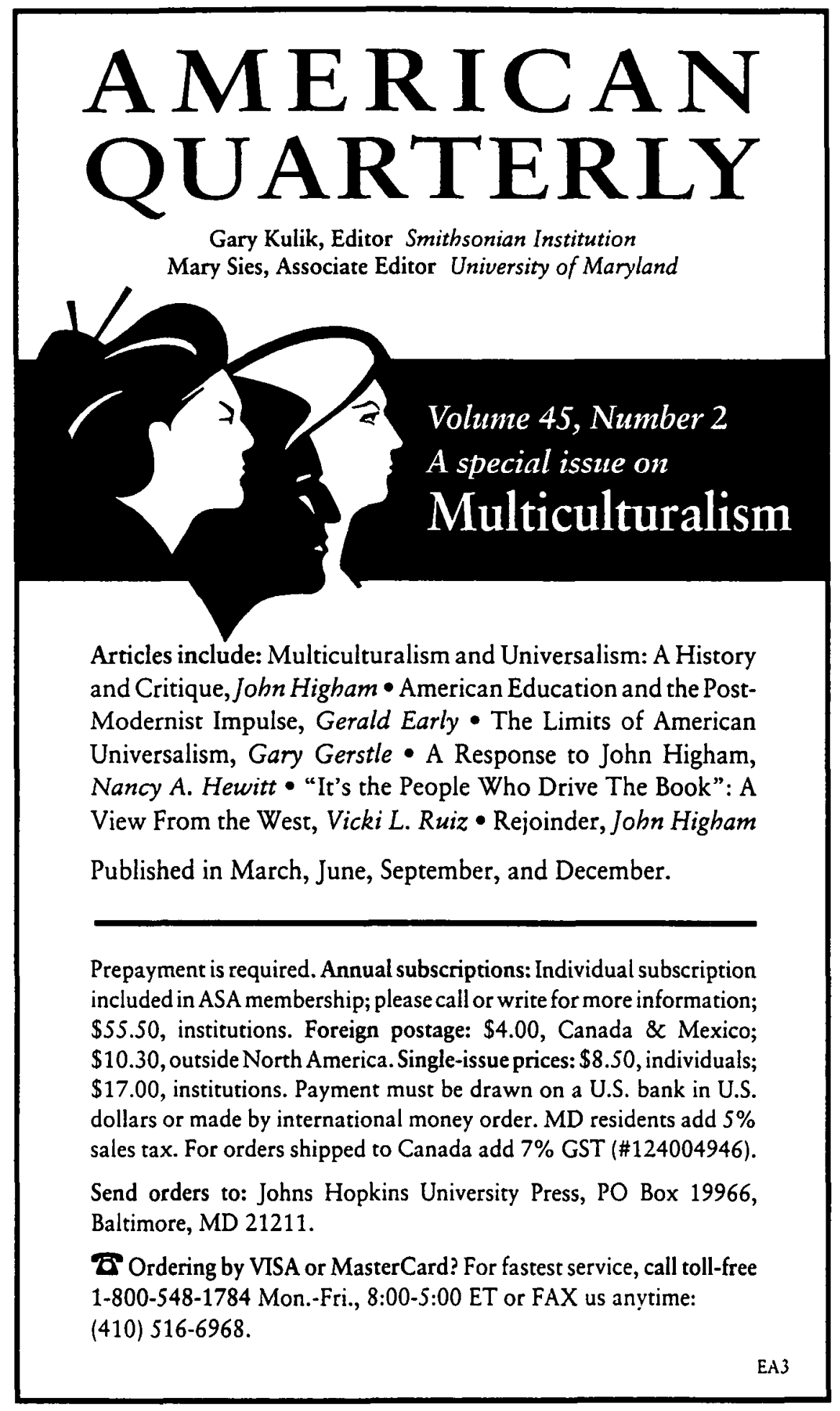




\section{Poor Fool}

A Novel by Erskine Caldwell

Voices of the South

An early novel by a master of the southern grotesque. $155 \mathrm{pp}, £ 9.50 \mathrm{pb}$

\section{The Last of the Southern Girls}

A Novel by Willie Morris

Voices of the South

"Willie Morris has written a witty, intelligent, and engaging book about Washington ... As a roman a clef it is great fun." - The New Republic 304pp, £10.95pb

\section{The Morning and the} Evening

A Novel by Joan Williams

Voices of the South

"The Morning and the Evening is indisputably the work of a greatly gifted writer. It is a haunting and beautiful tale, richly interfused with humor and sharp, unsettling insights into the human predicament." - William Styron $248 \mathrm{pp}, £ 10.95 \mathrm{pb}$

\section{Folk Roots and Mythic} Wings in Sarah Orne Jewett and Toni Morrison The Cultural Function of Narrative Marilyn Sanders Mobley "This is a richly suggestive study, a persuasive and valuable contribution to the reconceptualizing of the American literary canon."

- American Literature $193 \mathrm{pp}, £ 10.95 \mathrm{pb}$

\section{Purloined Letters}

Originality and Repetition in

American Literature

Joseph N. Riddel

Edited by Mark Bauerlein

An eminent theorist addresses the problem of "American" literature. 232pp, £28.50hb

\section{A Certain Slant of Light}

Regionalism and the Form of Southern and Midwestern Fiction David Marion Holman Introduction by Louis D. Rubin Jr. Southern Literary Studies An innovative study of the connection between regional awareness and imaginative achievement in the South and Midwest. $160 \mathrm{pp}, £ 23.95 \mathrm{hb}$

\section{The Novels of William}

\section{Styron}

From Harmony to History

Gavin Cologne-Brooks

Southern Literary Studies

This first full-length critical analysis of this major American novelist, uses the concept of narrative evolution, to illumine not only Styron's novels but also an entire genre. 288pp, $£ 28.50 \mathrm{hb}$

\section{LOUISIANA STATE} UNIVERSITY PRESS

c/o Academic \& University

Publishers Group

1 Gower Street

London WC1E 6HA

Tel: 01715803994 


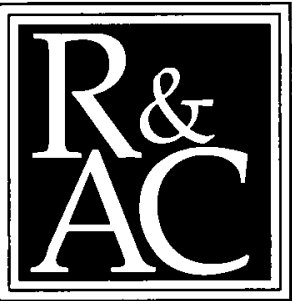

Religion \& American Culture

A Journal of Interpretation

\section{Editors •}

Religion and American Culture explores the interplay between religion and other spheres of American culture and embraces a diversity of methodological approaches and theoretical perspectives.

Conrad Sherry

Rowland Sherrill Jan Shipps

\section{Board of Editors}

Catherine Albanese William Dean Jay Dolan

Sam Gill

E. Brooks Holifield Richard Hughes Mark Noll Amanda Porterfield Wade Clark Roof John Roth Jonathan Sarna Winton Solberg Stephen Stein Peter Williams David Wills

Send orders to: Journals Division Indiana University Press $601 \mathrm{~N}$. Morton Bloomington, IN 47404

Phone: (812) 855-9449

Fax: (812) 855-8507

Email:

Journals@Indiana.Edu

\section{Religion and American Literature (Volume 6, Number 1)}

Kathleen Conzen, Brooks Holifield, Harry Stout, Michael Zuckerman: Forum on The Place of Religion in Urban and Community Studies

Una Cadegan: How Realistic Can a Catholic Writer Be? Richard Sullivan and American Catholic Literature

Robert Detweiler: Carnival of Shame:

Doctorow and the Rosenbergs

Ann-Janine Morey: In Memory of Cassie:

Child Death and Religious Vision in American Women Novelists

Kyle Pasewark: The Trouble with Harry: Freedom, America, and God in John Updike's Rabbit Novels

\section{Subscriptions (two issues)}

Individual, $\$ 20.00$

Institution, $\$ 30.00$

Surface post outside the USA, $\$ 7.00$

\section{Single Issues}

Individual, $\$ 10.00$

Institution, $\$ 20.00$

Postage and handling each, $\$ 1.75$ 
I All contributions and editorial correspondence should be sent to: The Editor, Journal of American Studies, History Department, Lancaster University, Lancaster LAI ${ }_{4}$ YG, England.

2 Articles should generally contain about 6,000 words. Longer or shorter articles, or articles in two or more parts, may be accepted by arrangement with the Editors.

3 Submission of an article is taken to imply that it has not previously been published, and has not been concurrently submitted for publication elsewhere.

4 Contributions should be clearly typed or printed in double spacing (including footnotes), with a wide left-hand margin. Diagrams, maps and illustrations may be included.

5 Spelling may conform either to British or American usage, providing it is consistent throughout.

6 Footnotes should be used sparingly: in general, to give sources of direct quotations, references to main authorities on disputable questions, and evidence relied on for a new or unusual conclusion. They should be numbered consecutively, and may most conveniently be placed, in double spacing, at the end of the article.

7 For guidance on matters of style, contributors should refer either to The Chicago Manual of Style (1 3 th edition, 1982) or to the Journal of American Studies Style Notes, copies of which may be obtained from the Editors.

8 Contributors should keep one copy of the typescript for correcting proofs.

9 Notes intended for the Editors or Printer should be on a separate sheet.

Io First proofs may be read and corrected by contributors provided that they can give the Editor an address through which they can be reached without delay and can guarantee to return the corrected proofs to the Editor, by airmail where necessary, within three days of receiving them.

I I Proof corrections should be kept to an absolute minimum. They should be confined to errors of the typist or printer unless the Editor authorizes otherwise.

I 2 Contributors of articles and review essays receive 25 free offprints. Extra copies may be ordered according to a scale of charges.

I 3 Contributors need not be members of the British Association for American Studies. Unsolicited typescripts can only be returned to overseas contributors who send International Reply Coupons (not postage stamps). Typescripts from the UK will not normally be returned.

I4 Contributors of accepted articles will be asked to assign their copyright, on certain conditions, to Cambridge University Press, to help protect their material, particularly in the USA.

Books for review should be sent as follows: History, Political Science and Social Studies to Professor Michael Heale, Department of History, Furness College, Lancaster University, Bailrigg, Lancaster LAI ${ }_{4} \mathrm{YG}$. Literature, the Fine Arts and other books to Professor Richard Gray, Department of Literature, University of Essex, Wivenhoe Park, Colchester

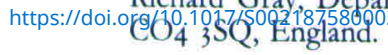




\section{Journal of}

\section{American}

\section{Studies}

$\begin{array}{lllllllllllll}\text { VOL M E } & 29 & \text { P A R T } & 2 & \text { A U G S T } & \text { I 995 }\end{array}$

The Political Culture of Emancipation: Morality, Politics, and the State in Garrisonian Abolitionism, $1854-1863$

MARK VOSS-HUBBARD

Why Shouldn't a Union Man Be a Union Man? The ILGWU and FOUR

PATRICK RENSHAW

The Politics of Gender, Language and Hierarchy in Mamet's "Oleanna"

CHRISTINE MACLEOD

\section{Notes and Comment}

Early Isolationism Revisited: Neutrality and Beyond in the $1790 \mathrm{~s}$ MARIE-JEANNE ROSSIGNOL

Dating Hemingway's Early Style/Parsing Gertrude Stein's Modernism DENNIS RYAN

State of the Art

Women's Place on the American Frontier

MARGARET WALSH

Reviews

\section{CAMBRIDGE} UNIVERSITY PRESS 